\title{
THE BEHAVIOURAL CONSEQUENCES OF PERCEIVED SERVICE QUALITY: A STUDY OF THE INDIAN TELECOMMUNICATION INDUSTRY
}

\author{
Deepika JHAMB (1) ${ }^{1}$, Amit MITTAL (D) ${ }^{*}$, Pankaj SHARMA (1)3 \\ ${ }^{1,2}$ Chitkara Business School, Chitkara University, Punjab, India \\ ${ }^{3}$ Tata Tele Services, Noida, India
}

Received 07 November 2019; accepted 17 January 2020

\begin{abstract}
The telecom industry in India has witnessed substantial growth over the last decade. Rapid growth of telecommunications is opening up the doors for many telecom players from Europe, Asia and other parts of the world, resulting in increased competition and tariff reductions. In the present competitive environment, the services perceived by the customers and their behavioural intentions play a pivotal role in the customer switching process among service providers. With the changing expectations of service quality, it becomes imperative to discover the gap between customer expectations and customer perception. In this context, the aim of the present study is to identify the existing gap between customer expectations and perceptions and investigate the relationship between post-experience perception of service quality and customers' behavioural intentions. The data was collected from 500 customers in Delhi NCR, India. Paired sample t-test and multiple correlation analysis were performed. The results of the study points out the key areas wherein the service gaps are considerably high such as reliability and responsiveness. The customer behavioural intentions, such as "Complain to customer service if a problem occurs", "Switch to another service provider" and "Reducing the usage with a particular service provider", have shown a strong relationship with quality of service. The findings of the study confirm that the perceptions of customers regarding the quality of service received definitely have an impact on their behaviour.
\end{abstract}

Keywords: service quality, expectations, perceptions, behavioural intentions, telecom service providers.

JEL Classification: L80, L96, D10.

\section{Introduction}

The telecommunication sector has emerged as one of the key sectors that significantly contribute to the growth of the Indian economy. Liberalization of government policies, Favourable demographics, changing lifestyles and increasing growth opportunities have made India an attractive destination for telecom service providers. The Indian telecommunications network is the second-largest network after China in the number of telephone connections (Mani, 2005; Yadav, 2014). As per the Telecom Regulatory Authority of India (2017), the telecom sector had only 898.02 million overall telephone subscribers in March 2013, and the number increased to 1206.71 million at the end of September 2017, showing an addition of 308.69 million. This increase is entirely due to an increase in the wireless connections from 867.04 million at the end of September 2013 to 1183.04 by end of March 2017. It contributes nearly two per cent of the country's gross domestic product and, it has become one of the world's most competitive and fastest-growing telecom markets (Shine,
2013; Yadav, 2014; Patel, 2018). In addition, strong consumer demand has also helped to revive the sector. Moreover, the Indian telecom industry is playing a significant role along with the Government of India's move for empowering its population by converting India into a digital economy (Ministry of Electronics and Information Technology, 2018). At the same time, success will not come just by changing business models and innovating new ways to generate revenue, but by looking at improving the quality of services and considering the users' opinion and their changing mind-sets (Ojiaku \& Osarenkhoe, 2018). With rising expectations and growing awareness, consumers in India are increasingly demanding superior quality services (Chopra \& Chawla, 2018). Although, these operators are struggling to ensure what customers perceive and expect in order to sustain their customers, the increase in subscribers' switching behaviour to other service providers is also a matter of concern (Pandey \& Kumar, 2018).

The existing literature is rich in explaining the relationships between the perceived service quality and customer

*Corresponding author. E-mail: amit.mittal@chitkara.edu.in 
behavioural intentions (Ryu et al., 2012; Min \& Khoon, 2014; Selvakumar, 2016; Kondasani \& Panda, 2016; AlHashedi \& Abkar, 2017; Pedro, Mendes, \& Lourenço, 2018; Mathew, Narayanan, \& Mittal, 2019). For instance: Ryu, Lee, and Gon Kim (2012) examined the impact of foodservice quality dimensions on restaurant image, customer perceived value, satisfaction and behavioural intentions. Selvakumar (2016) investigated the impact of service quality on customer satisfaction in private and public sector banks. Kondasni and Panda (2016) analysed how customers' service quality perception leads to positive behavioural intentions towards service providers. Similar to these, Al-Hashedi and Akbar (2017) attempted to identify the impact of service quality dimensions on customer satisfaction in telecom mobile companies in Yemen. Pedro et al. (2018) also tried to identify the association between perceived service quality and satisfaction in higher education. Nevertheless, scientific academic literature lacks a study that can clarify the difference between customer expectations and perceptions about service quality delivery as well as the relationship between perceived service quality and customers' behavioural intentions in the context of the telecom sector. Likewise, the majority of the studies on telecommunication industry in relation to service quality typically represent contexts found in developed countries. Recently, in 2018, the Indian government unveiled the National Digital Communication Policy aiming to attract USD 100 billion investment by 2022. Meanwhile, the market revenue of the sector is targeted to cross USD 26.38 billion by 2020 with 829 million internet subscribers by 2020 (IBEF, 2019). Looking at the government's move towards the digital India program and increasing demand from customers, there is an urgent need to improve the telecom service quality in India (Siwach \& Kumar, 2015; Dua, 2017; Prasad, 2018). To achieve these aims, there is an urgent need to develop a deep understanding about dimensions of service quality, customers' expectations, customers' perceptions, and behavioural intentions towards service providers. Therefore, this study aims to bridge the aforementioned research gap through investigating the difference between customer expectations and perceptions related to service quality delivery as well as the relationship between the post-experience perception of service quality and customers' behavioural intentions in the context of the Indian telecom sector.

With this specific background in terms of quality of service, the findings of the study reveal that reliability and responsiveness are found below consumer expectations and demand attention from telecommunication service providers. Moreover, the results also signify that the quality of service received definitely has an influence on customer buying behaviour. The outcomes of the study encourage the recommendation that telecommunication marketers must evaluate the perceived service quality and the customer's behavioural intentions to ensure seamless services (Sharma \& Jhamb, 2017; Sharma, 2017). The present study is also expected to pave the way for telecom companies to sustain intense competition in the market by identifying the key service quality indicators. The theoretical basis of this research is to provide policy-makers with the idea of customers' expectations from telecommunications service providers to ameliorate the telecommunication services.

The remainder of the paper is organised as follows. The literature review and hypotheses development is reported in Section 1. Section 2 presents the research methods which includes the major constructs, instrument development, data collection, reliability and validity. Section 3 deals with results and discussions and the final section include the conclusions and implications, recommendations, limitations, and future research directions.

\section{Literature review \& hypotheses development}

The telecommunication sector in India has developed rapidly in terms of customer base and revenue generation over the last ten years (Yadav, 2014; Kumar, Shankar, \& Debnath, 2015; Dubey \& Srivastava, 2016). The telecommunication market has become a great opportunity for network providers of native and exogenous players and both service providers are gaining significant market shares (Baruah \& Baruah, 2014). This trend has led to enhanced customer expectations for better service quality, and their behavioural impact shows a significant change in growth trends and switching behaviour to other operators (Kushwah \& Bhargav, 2014). Service providers are struggling to meet the customer expectations, and there has been stiff competition among the service providers in terms of network availability, call clarity, internet access via mobile and other value-added services (Paulrajan \& Rajkumar, 2011; Yadav, 2014). Hence, there is heavy competition among these players to meet the expectations for both existing and new customers. This is a significant matter of concern for telecom service operators to retain the customer by providing various offers with improved service quality. Hence, this study focuses on examining how customers perceive the delivered services, what kind of different expectations they have in mind, and finally, what they see as unfulfilled expectations (i.e., gaps).

The first phase of the literature focuses upon service quality and its dimensions. It emphasizes the various aspects of service quality that cover the gaps between customer expectations and perceptions and their behavioural intentions. In the global cutthroat situation, the quality of services offered is considered an important strategy to retain customers (Parasuraman, Zeithaml, \& Berry, 1985; Reichheld \& Sasser, 1990; Zeithaml, Parasuraman, \& Berry, 1990). Most of the developments were focused on service quality due to the revolutionary and continuous efforts by Parasuraman, Berry, and Zeithaml (1985, 1991). Their research has created an accepted conceptual framework (Service Quality Gap Model) and a measurement instrument "SERVQUAL" to evaluate service quality. Studies by Ojo (2010), Loke et al. (2011), and Naseer, 
$\mathrm{Hu}$, and Fukuda (2012) show the gaps found in customer expectations and perceptions and suggest focusing on narrowing the gap. The provision of high quality services is related to benefits, reserves and market share (Zeithaml et al., 2000; Munusamy et al., 2010). Also, service providers must meet consumer needs and maintain price as well as quality of service. Johnson and Sirikit (2002) conducted a survey on wire-line and mobile phone users in Thailand's telecommunication industry using the following five dimensions of service quality: tangibility, reliability, responsiveness, assurance and empathy. Although tangible dimension emerged as the most important factor, no significant relationship was found between the service quality and customer behavioural intention. Wong and Dioko (2013) and Lo (2002) investigated the relationships among service quality, customer satisfaction, customer value and their influences on customers' future behaviours in the telecommunication industry of China using the "SERVQUAL" model and concluded that network quality is one of the most important drivers of overall service quality, customer satisfaction and customer value. Better service quality brings various aspects such as improvement in customer loyalty, expansion of market share, high profitability to investors, operation cost reduction and improvement of the market (Howat, Crilley, \& McGrath, 2008; David, 2013; Zehendner and Feillet, 2014). SERVQUAL proposes to review service quality in five dimensions: tangibility, reliability, responsiveness, assurance and empathy. The gap score is calculated by subtracting the perceptual score from the expected score. A positive score indicates that the service exceeds the customer's expectation, while a negative gap indicates that the actual service is of a lower level than expected. Negative gaps are the areas for improvement (Qadri, 2015; Lee et al., 2016; Cruz \& Mendes, 2019). This concept forms the base for this theoretical framework. Very few studies focused on comparative analysis of service quality and customers' expectations as well as perceptions of telecom service providers in India. Hence, the intention of this study is to focus on the quality of service and on identifying the gap between customer expectations and perceived services.

The second phase of the literature tries to identify the customer behavioural intention attributes influencing consumers' perceptions. The customer behavioural intentions are the behaviour activities to promote the brand, repurchase service/product, price point's comparisons and complaints. Parasuraman, Zeithaml, and Berry (1988) pointed out that there is a significant relationship between the services perceived by the customers' and their intentions to recommend the services to other customers. Anderson (1973), Bolton and Drew (1991), and Olshavsky and Miller (1972) also examined the affect of unconfirmed expectations on the customers product performance ratings. Specific indicators of positive customer behavioural intentions can be compiled by conveying positive things and recommending the service provider to others (Parasuraman et al., 1988; Parasuraman et al., 1991; Reichheld \& Sasser, 1990; Choudhury, 2014; Cruz \& Mendes, 2019).
Ravichandran et al. (2010) conducted a study to assess the impact of service quality dimensions on customer behavioural intentions in the Indian Banking Sector. The results of the study concluded that service quality dimensions such as tangibility, responsiveness and empathy play an essential role in forecasting customers' behavioural intentions. Rao et al. (2016) conducted a survey to analyze how customers' perception leads to positive behavioural intentions towards the service providers. The result of the study states that the factors "reliability" and "security and data protection" do not significantly contribute to a positive behavioural intention. This finding inevitably highlighted the organization's inability to meet customer expectations in this area. According to Choudhury (2014), Uppal and Mittal (2019) perceived dimensions of service quality have a strong impact on customers' complaining behaviour that can further be influenced by employees' attitudes. The study by Cruz and Mendes (2019) also concluded that users' satisfaction is the major determinant for their behavioural intentions. So, the present study also examines the relationship between customer behaviour intentions and the overall perceived service quality in the context of the Indian telecommunication industry.

Based on the above discussion, the study hypothesizes that:

H1: There is a significant difference between the customer expectations and perceptions of service quality delivered.

$\mathrm{H} 2$ : There is a significant relationship between the overall perceived service quality and customer behaviour intentions.

\section{Research methods}

\subsection{Constructs}

The present study has conducted the primary research with the telecom service users (mobile phone), calculation of gap between perceptions and expectations via SERVQUAL dimensions and relationship examination of customer behavioural intentions (dimensions) with customer perceived service quality. To fulfil the objective, the study has used the following four constructs as explained below: dimensions of service quality, customer expectations, customer perceptions and customer behavioural intentions.

\section{Dimensions of service quality}

Parasuraman et al. $(1988,1990)$ identified and developed a five-dimensional model for evaluating the service quality: tangibility, reliability, responsiveness, assurance and empathy. Tangibility includes equipment, personnel (outward show of service provider) and communications (Pitt, Watson, \& Kavan, 1995). Reliability is related to service consistency as it indicates the capacity to act upon the promised services reliably and correctly (Babakus \& Mangold, 1992; Chowdhary \& Prakash, 2007). Responsiveness implies a readiness to help customers (Liang, Chang, \& Wang, 2011). Assurance means the 
ability to communicate employee knowledge, courtesy and trust. Empathy is about providing attentive and personalized consideration to customers including access, ease of communication and customer perceptions (Berry, Parasuraman, \& Zeithaml, 1994).

\section{Customer expectations}

Based on known experience or through word-of-mouth communication, people develop some expectations from a service provider. The expectations vary for each customer and may change based on the need, situation and requirements (Manohar, Mittal, \& Marwah, 2019). Customers' expectations are raised by listening to advertisements and promotions of service providers. According to Zeithaml, Parasuraman, and Malhotra (2000) customer expectations are a belief in service delivery. Customer expectations can be categorized into different levels. Various researchers such as Zeithaml, Bitner, and Gremler (1996) divided the expectations into five levels: the ideal level of service, the desired level, the adequate service level, expected service level and the tolerance zone.

\section{Customer perceptions}

The customer considers service quality as a divergence between customer expectations and their perceptions of services. These perceptions result from a comparison between customer expectations and service experience awareness (Zeithaml et al., 1990). In case the customer expectations are superior to the performance, the perceived quality of service is inadequate, and therefore customers' experience dissatisfaction (Parasuraman et al., 1985; Lewis \& Mitchell, 1990). Consequently, it is understood that if expectation exceeds perception, the service is considered excellent. If the value of expectations is equal to perceptions, the service is considered good; if the expected value is not satisfied, then the service is deemed to be poor. Overall assessment of perceived services relies on the differences between customers' expectations and their perceptions.

\section{Customer behavioural intentions}

Several researchers have suggested that behavioural intentions are an indicator of whether a customer will stay with an organization or go away (Kang et al., 2002; Alexandris et al., 2004). Customer behavioural intentions can be understood as their behavioural activities to promote the brand, purchase service/product, price point's comparisons, and complaints. Parasuraman et al. (1988) proved a significant link between the customers' perceived services and their willingness to suggest other companies. Anderson (1973), Bolton and Drew (1991); Olshavsky and Miller (1972) also examined the effect of unconfirmed expectations on customers' product performance ratings. All these studies have concluded that satisfaction positively influences consumer attitudes and dissatisfaction negatively impacts them. As stated by Cronin and Taylor (1992); Zeithaml et al. (1996) customer behavioural intentions can be divided into the following four dimensions: word-of-mouth communications, purchase intentions, price sensitivity and complaining behaviour.

\subsection{Instrument development}

The instrument is prepared using two existing scales. The "SERVQUAL scale" developed by Parasuraman, Zeithaml and Berry (1988) is used to measure customers' expectations and perceptions towards telecom service providers in India. It includes 22 statements each and consists of five dimensions: Tangibility, Reliability, Responsiveness, Assurance and Empathy. According to Parasuraman et al. (1988) "SERVQUAL can be used in its present form to assess and compare quality across a wide variety of firms." The second scale, which is the "13-items behavioural intention scale" developed by "Zeithaml, Berry and Parasuraman (1996), is used to measure the behavioural intentions of the respondents. It includes four dimensions: Word-of-Mouth Communication, Purchase Intentions, Price Sensitivity and Complaining Behaviour." The instrument was designed on a seven-point Likert scale ranging from "strongly disagree" (1) to "strongly agree" (7) to measure the service quality and customer behavioural intentions. The above scales have been used by carefully analysing the literature, as these scales are commonly used in the previous studies to measure service quality and customers' behavioural intentions (Ladhari, 2009). Table 1 indicates the standardized scales used to measure each construct, the number of indicators of each construct, the sources that were used and the number of citations of those sources by previous researchers as represented on the Google Scholar platform.

Table 1. Number of indicators and scales for construct measures (source: author's compilation)

\begin{tabular}{|l|c|l|l|c|}
\hline \multicolumn{1}{|c|}{ Constructs } & $\begin{array}{c}\text { Number of } \\
\text { Indicators }\end{array}$ & \multicolumn{1}{|c|}{ Scale } & \multicolumn{1}{c|}{ Source } & $\begin{array}{c}\text { Google Scholar's Citation } \\
\text { as on } 11.12 .2019\end{array}$ \\
\hline Customers' Expectations & 22 & SERVQUAL & Parasuraman, Zeithaml, and Berry (1988) & 32857 \\
\hline Customers' Perception & 22 & SERVQUAL & $\begin{array}{l}\text { Parasuraman, Zeithaml, and Berry (1985, } \\
1988)\end{array}$ & 32857 \\
\hline $\begin{array}{l}\text { Customer Behavioural } \\
\text { Intentions }\end{array}$ & 13 & $\begin{array}{l}\text { Behavioural } \\
\text { Intention Scale }\end{array}$ & Zeithaml, Berry, and Parasuraman (1996) & 13918 \\
\hline
\end{tabular}




\subsection{Data collection}

To carry out the current study, the quantitative approach was followed. The study examined 500 customers as respondents for collecting data from Delhi/NCR. To collect the data from 500 customers, the questionnaire was distributed to 1200 respondents to enhance the scope of early data collection. Out of the total questionnaires distributed, 500 complete questionnaires were received by the respondents with response rate of $41.67 \%$. The reason for selecting Delhi/NCR as a sample is that this region has the highest Tele-density in India as per the Telecom Regulatory Authority of India. Delhi has the highest Teledensity at $262.12 \%$ as on 31 st July 2017. Quota sampling technique was followed.

\subsection{Demographic profile of the respondents}

Out of the 500 respondents surveyed, 65 per cent were male and 35 per cent were female. Majority of respondents were between 26 and 30 years of age followed by up to 25 years (33 per cent). Respondents were post-graduates and graduates in their academic qualifications. 17 per cent of the respondents were undergraduates. Most of the respondents, i.e., 58 per cent belong to service class followed by business and others. Sample respondents falling between the monthly income groups from Rs. 40,001-80,000 had a dominant share of 35 per cent.

\subsection{Reliability and validity}

Though the "SERVQUAL" and "13-items behavioural Intentions Scale" are commonly used in the literature to measure service quality and customer behavioural intentions in different industry set-ups, it becomes imperative to check the validity and reliability of the instrument before testing the research claims (Kirk et al., 1986; Yore et al., 2007). The face validity of the instrument has been checked by conducting an experiential survey of six experts from the field of industry/academia as depicted in Table 2. The experiential survey allows researchers to gain information from specialists in a similar field and provide freedom to the experts for demonstrating their knowledge (Zikmund et al., 2013). The following two criteria were followed while choosing the experts for instrument validation:

1. Year of Experience (Minimum 15 Years);

2. Area of Expertise (Service Quality \& Consumer Behaviour).

To further assess the reliability and validity of the instrument, the Cronbach's Alpha, Average Variance Extracted and Composite Reliability was applied as depicted in Table 3 and Table 4. The Chronbach Alpha values for all the dimensions of service quality and customer behavioural intentions lie in between 0.709 and 0.879 . If the Cronbach's Alpha value is more than 0.70 , it is considered a good reliability score (Cronbach, 1951; Brown, 2002; Aggarwal et al., 2018). The instrument demonstrates evidence of convergent validity (average variance extracted $>0.50$ in all constructs) and composite reliability (values $>0.70$ in all constructs) (Fornell \& Larcker, 1981; Hair et al., 2010).

Table 2. Experiential survey (source: author's compilation)

\begin{tabular}{|c|c|c|c|}
\hline Expertise & Interaction & Profile & Inputs \\
\hline Telecom & Personal Meeting & $\begin{array}{l}\text { National Customer Service } \\
\text { Head } \\
\text { (Sr. Vice President) }\end{array}$ & $\begin{array}{l}\text { 1) Keep it simple or use simple language for more customers } \\
\text { understanding. } \\
\text { 2) Need to have some brief on behavioural Intentions section } \\
\text { for understanding. }\end{array}$ \\
\hline Audit Firm & Mail & $\begin{array}{l}\text { Telecom, Customer Insight } \\
\text { Analyst } \\
\text { (Director) }\end{array}$ & $\begin{array}{l}\text { 1) Shared sample survey formats to take inputs. } \\
\text { 2) Suggested to keep one section in sheet for easiness to } \\
\text { respondents. }\end{array}$ \\
\hline Banking & Mail & Banking (First Vice President) & 1) Find it appropriate for the purpose of the survey. \\
\hline Telecom & $\begin{array}{l}\text { Telephonic/ } \\
\text { Mail }\end{array}$ & $\begin{array}{l}\text { Customer Experience and } \\
\text { Business Development Leader } \\
\text { (Sr. Vice President) }\end{array}$ & $\begin{array}{l}\text { 2) You may use different instrument for both Expectation and } \\
\text { Perception to have more accuracy. } \\
\text { 3) Find it good to have such survey as proper scales are } \\
\text { referred. }\end{array}$ \\
\hline $\begin{array}{l}\text { Management } \\
\text { Consulting } \\
\text { International } \\
\text { Firm }\end{array}$ & Mail & $\begin{array}{l}\text { Management Consulting } \\
\text { (Head of Business } \\
\text { Development and Strategy) }\end{array}$ & $\begin{array}{l}\text { 1) Add new launched operators like "Reliance Jio" etc. } \\
\text { 2) Multiple operators to be there. } \\
\text { 3) Should have instrument on pricing and tariff. } \\
\text { 4) Customer expectations/perceptions about Operator App, } \\
\text { social media support } \\
\text { 5) Section III: Please put } 2-3 \text { lines of explanation at the start of } \\
\text { the section }\end{array}$ \\
\hline University & $\begin{array}{l}\text { Mail/ } \\
\text { Meeting }\end{array}$ & $\begin{array}{l}\text { Management (Associate } \\
\text { Professor) }\end{array}$ & $\begin{array}{l}\text { 1) Find it appropriate for the purpose of said survey. } \\
\text { 2) Need to little ease the statements mentioned. } \\
\text { 3) Need some brief on BI section. }\end{array}$ \\
\hline
\end{tabular}


Table 3. Reliability scores of service quality dimensions

\begin{tabular}{|l|c|c|c|c|c|c|c|}
\hline \multicolumn{1}{|c|}{$\begin{array}{c}\text { Service } \\
\text { Quality } \\
\text { Dimensions }\end{array}$} & $\begin{array}{c}\text { No. of } \\
\text { Items }\end{array}$ & $\begin{array}{c}\text { Expectations } \\
\text { Cronbach's } \\
\text { Alpha } \\
\text { Value }\end{array}$ & $\begin{array}{c}\text { Expectations } \\
\text { Average } \\
\text { Variance } \\
\text { Extracted }\end{array}$ & $\begin{array}{c}\text { Expectations } \\
\text { Composite } \\
\text { Reliability }\end{array}$ & $\begin{array}{c}\text { Perceptions } \\
\text { Cronbach's } \\
\text { Alpha } \\
\text { value }\end{array}$ & $\begin{array}{c}\text { Perceptions } \\
\text { Average } \\
\text { Variance } \\
\text { Extracted }\end{array}$ & $\begin{array}{c}\text { Perceptions } \\
\text { Composite } \\
\text { Reliability }\end{array}$ \\
\hline Tangibles & 4 & 0.727 & 0.507 & 0.804 & 0.796 & 0.559 & 0.863 \\
\hline Reliability & 5 & 0.736 & 0.635 & 0.839 & 0.718 & 0.601 & 0.857 \\
\hline $\begin{array}{l}\text { Respon- } \\
\text { siveness }\end{array}$ & 4 & 0.713 & 0.559 & 0.860 & 0.757 & 0.568 & 0.839 \\
\hline Assurance & 4 & 0.798 & 0.521 & 0.778 & 0.758 & 0.582 & 0.847 \\
\hline Empathy & 5 & 0.709 & 0.532 & 0.848 & 0.792 & 0.570 & 0.840 \\
\hline
\end{tabular}

Table 4. Reliability scores of customer behavioural intentions

\begin{tabular}{|l|c|c|c|c|}
\hline $\begin{array}{c}\text { Behavioural Intentions } \\
\text { Dimensions }\end{array}$ & No. of Items & Cronbach's Alpha value & $\begin{array}{c}\text { Average Variance } \\
\text { Extracted }\end{array}$ & Composite Reliability \\
\hline Word-of-Mouth & 3 & 0.773 & 0782 & 0.915 \\
\hline Purchase Intention & 3 & 0.867 & 0717 & 0.883 \\
\hline Price Sensitivity & 3 & 0.804 & 0.807 & 0.926 \\
\hline Complaining Behaviour & 4 & 0.879 & 0.651 & 0.879 \\
\hline
\end{tabular}

\section{Results \& discussions}

The first objective is to examine the gap between customer expectations and perceptions of service quality delivered by Indian telecommunication service providers. This goal was achieved by using the SERVQUAL scale, which is used to assess the customer expectations and perceptions of the quality of service. The average value of each dimension (tangibility, reliability, responsiveness, assurance and empathy) is examined and compared in between expectations and perceptions.

Table 5 shows that the largest average gap emerged between customer expectations and perceptions under the dimensions of reliability and responsiveness. In terms of reliability, there exists $31.5 \%$ gap between expectation and perception followed by $29.3 \%$ in responsiveness. Empathy and assurance both have a gap of $13.7 \%$ between expectation and performance. About $10.4 \%$ gap is observed in tangibility.

Further, the paired sample t-test was applied to compare the means between two related groups i.e., expectations and perceptions of mobile phone users (Table 6). It calculates the differences between the values of the two variables for each case and tests whether the value of the difference deviates from 0 . Hence, this technique is found suitable for testing the first hypothesis.

The values of mean scores under Expectations range from 5.038 to 5.282. Similarly, the mean score values under Perceptions range from 3.449 to 4.578 . As shown in above table, the mean difference is higher in the case of "Reliability" dimension followed by "Responsiveness". Since the p-value in all cases is below 0.05 , the alternative hypothesis ( $\mathrm{H} 1)$ can be accepted. Hence, there is significant difference between customer expectations and perceptions, across the five dimensions of SERVQUAL.

To achieve the second objective for analysing the relationship between perceived service quality and customer behavioural intentions, Pearson's Correlation and Multiple Linear Regression analysis was performed as depicted in Table 7 and Table 8.

With overall Services Quality perception, the complaint score has a correlation coefficient of 0.887 that is strong and significant (at 99\% confidence interval) followed by word-of-mouth communication score (0.885), purchase intention (0.789) and price sensitivity (0.729). From the above analysis, it is concluded that there is a

Table 5. Expectations and perceptions: dimension wise mean score

\begin{tabular}{|l|c|c|c|l|}
\hline \multicolumn{1}{|c|}{ Dimensions } & $\begin{array}{c}\text { Expectation } \\
\text { (Mean Score) }\end{array}$ & $\begin{array}{c}\text { Performance Score } \\
\text { (Mean Score) }\end{array}$ & $\begin{array}{c}\text { Gap } \\
(\mathrm{P}-\mathrm{E})\end{array}$ & Gap \% difference w.r.t to expectation \\
\hline Tangibles & 5.109 & 4.578 & -0.531 & Service providers perform 10.4\% less than the expected level \\
\hline Reliability & 5.038 & 3.449 & -1.589 & Service providers perform 31.5\% less than the expected level \\
\hline Responsiveness & 5.282 & 3.734 & -1.548 & Service providers perform 29.3\% less than the expected level \\
\hline Assurance & 5.198 & 4.486 & -0.712 & Service providers perform 13.7\% less than the expected level \\
\hline Empathy & 5.228 & 4.506 & -0.722 & Service providers perform 13.8\% less than the expected level \\
\hline
\end{tabular}

Note: Tangibles $100-(4.578 / 5.109) \times 100=10.4 \%$. 
Table 6. Paired sample T-test between customers' expectations and perceptions

\begin{tabular}{|c|c|c|c|c|c|c|c|}
\hline \multirow{3}{*}{$\begin{array}{l}\text { Dimensions } \\
\quad \text { (pair } \\
\text { comparisons) }\end{array}$} & \multicolumn{5}{|c|}{ Paired Differences } & \multirow{3}{*}{$\mathrm{T}$} & \multirow{3}{*}{$\begin{array}{c}\text { Sig. } \\
\text { (2-tailed) }\end{array}$} \\
\hline & \multirow{2}{*}{$\begin{array}{c}\text { Mean } \\
\text { (difference) } \\
(\mathrm{P}-\mathrm{E})\end{array}$} & \multirow{2}{*}{$\begin{array}{l}\text { Std. } \\
\text { Deviation }\end{array}$} & \multirow{2}{*}{$\begin{array}{l}\text { Std. Error } \\
\text { Mean }\end{array}$} & \multicolumn{2}{|c|}{$\begin{array}{l}\text { 95\% Confidence Interval of the } \\
\text { Difference }\end{array}$} & & \\
\hline & & & & Lower & Upper & & \\
\hline Tangibles & -0.53 & 0.93 & 0.04 & -0.61 & -0.45 & -12.72 & 0.001 \\
\hline Reliability & -1.59 & 0.79 & 0.04 & -1.66 & -1.52 & -44.83 & 0.001 \\
\hline Responsiveness & -1.55 & 0.90 & 0.04 & -1.63 & -1.47 & -38.46 & 0.001 \\
\hline Assurance & -0.71 & 0.89 & 0.04 & -0.79 & -0.63 & -17.96 & 0.001 \\
\hline Empathy & -0.72 & 0.74 & 0.03 & -0.79 & -0.66 & -21.88 & 0.001 \\
\hline
\end{tabular}

Note: For all the cases, the degrees of freedom is 499 , Total records -1 mean $=499$ ).

Table 7. Correlation analysis: perceived service quality and customer behavioural intentions

\begin{tabular}{|c|c|c|c|c|c|c|c|c|c|c|}
\hline & $\begin{array}{l}\text { Tangibles } \\
\text { (P) }\end{array}$ & $\begin{array}{c}\text { Relia- } \\
\text { bility (P) }\end{array}$ & $\begin{array}{l}\text { Respon- } \\
\text { siveness } \\
\text { (P) }\end{array}$ & $\begin{array}{c}\text { Assur- } \\
\text { ance }(P)\end{array}$ & $\begin{array}{l}\text { Empathy } \\
\text { (P) }\end{array}$ & $\begin{array}{l}\text { Word of } \\
\text { Mouth }\end{array}$ & $\begin{array}{l}\text { Purchase } \\
\text { Intention }\end{array}$ & $\begin{array}{l}\text { Price } \\
\text { Sensi- } \\
\text { tivity }\end{array}$ & $\begin{array}{l}\text { Compl- } \\
\text { aints }\end{array}$ & $\begin{array}{c}\text { Overall } \\
\text { Perceived } \\
\text { Service } \\
\text { Quality }\end{array}$ \\
\hline Tangibles (P) & 1 & & & & & & & & & \\
\hline Reliability (P) & 0.041 & 1 & & & & & & & & \\
\hline Responsiveness (P) & $0.151^{* *}$ & -0.074 & 1 & & & & & & & \\
\hline Assurance (P) & $0.235^{* *}$ & 0.018 & 0.045 & 1 & & & & & & \\
\hline Empathy (P) & $0.213^{* *}$ & 0.070 & $0.108^{*}$ & 0.041 & 1 & & & & & \\
\hline Word-of-Mouth & $0.574^{* *}$ & $0.368^{* *}$ & $0.390^{* *}$ & $0.478^{* *}$ & $0.479^{* *}$ & 1 & & & & \\
\hline Purchase Intention & $0.510^{* *}$ & $0.341^{* *}$ & $0.327^{* *}$ & $0.412^{* *}$ & $0.449^{* *}$ & $0.843^{* *}$ & 1 & & & \\
\hline Price Sensitivity & $0.463^{* *}$ & $0.330^{* *}$ & $0.282^{* *}$ & $0.405^{* *}$ & $0.402^{* *}$ & $0.814^{* *}$ & $0.956^{* *}$ & 1 & & \\
\hline Complaint & $0.582^{* *}$ & $0.367^{* *}$ & $0.381^{* *}$ & $0.483^{* *}$ & $0.481^{* *}$ & $0.934^{* *}$ & $0.842^{* *}$ & $0.810^{* *}$ & 1 & \\
\hline $\begin{array}{l}\text { Overall Perceived } \\
\text { Service Quality }\end{array}$ & $0.641^{* *}$ & $0.429^{* *}$ & $0.448^{* *}$ & $0.507^{* *}$ & $0.561^{* *}$ & $0.885^{* *}$ & $0.789^{* *}$ & $0.729^{* *}$ & $0.887^{* *}$ & 1 \\
\hline
\end{tabular}

Notes: ${ }^{*}$ Correlation is significant at the 0.01 level (2-tailed). ${ }^{\star}$ Correlation is significant at the 0.05 level (2-tailed).

Table 8. Regression analysis: customer behavioural intentions and overall perceived service quality

\begin{tabular}{|l|c|c|c|c|}
\hline \multicolumn{1}{|c|}{ Customer Behavioural Intentions } & $\beta$ & Beta & $\mathrm{T}$ & $\mathrm{p}$ \\
\hline Word-of-Mouth Communication & 0.137 & 0.414 & 70.425 & 0.000 \\
\hline Purchase Intentions & 0.126 & 0.385 & 50.219 & 0.000 \\
\hline Price Sensitivity & -0.114 & 0.358 & -50.291 & 0.000 \\
\hline Complaining Behaviour & 0.136 & 0.462 & 80.289 & 0.000 \\
\hline
\end{tabular}

Notes: $\mathrm{R}^{2}=0.813$, Adjusted $\mathrm{R}^{2}=0.812$, F statistics $=539.636$, Significance $(\mathrm{F}$ statistics $)<0.001$.

Dependent Variable: Overall Perceived Service Quality.

significantly strong relationship between the dimensions of customers' behavioural intentions and overall perceived service quality.

Further multiple linear regression analysis has been used to identify the important predictors of the overall perceived service quality. Thus, using overall perceived service quality as a dependent variable and four dimensions of customer behavioural intentions (Word-of-Mouth Communications, Purchase Intentions, Price Sensitivity and Complaining behaviour) as an independent variable, step-wise multiple regression analysis has been conducted.
The results of regression analysis also support that the complaining behaviour is the important predictor of overall perceived service quality as it scores the highest $\beta$ value $(0.462)$ followed by word-of-mouth communications (0.414), purchase intentions (.385) and price sensitivity (0.358). Overall, the regression model explained $81.2 \%$ of variation in all the dimensions of customer behavioural intentions. Above results confirm the alternate hypothesis $(\mathrm{H} 2)$ that there is a significant relationship between the overall perceived service quality and the customer behavioural intentions. So, (H2) is also accepted. 


\section{Conclusions and implications}

The present study investigates the gap between expectations and perceptions of service quality dimensions and the relationship between perceived services and behavioural intentions of customers based on the data collected from customers of Indian telecommunication sector. It has been found that customer perception towards telecom services is significantly prompted via five dimensions, viz. tangibility, reliability, responsiveness, assurance and empathy." However, the dimensions of reliability and responsiveness have the most significant impact, whereas tangibility has the least impact on customers' perception towards telecommunication services. Reliability dimension entails consistency of overall performance and dependability. Specifically, it involves accuracy in billing and resolving the complaints within the designated time. Out of the five aspects of reliability dimension, customer feedback has revealed that the largest gap exists in "providing services as per the committed timeframe" as is evident from the highest mean difference value of -1.80 . The second largest gap lies in the area 'Perform services right in the given time, followed by "Service providers are reliable" with the respective mean varies of -1.70 and -1.56 . Responsiveness refers back to the inclination or the will of the employees to provide good services. This includes schedules for the services provided such as calling the customer back quickly to update complaint/query status, updating the transaction intimation immediately and giving prompt updates (e.g., new updates and offers). Of all the four aspects of the responsiveness dimension the largest gap exists in the "Offers prompt service for customers", followed by "Informing customers when services will be performed", "Readily respond to the customers' request", and "Always willing to help customer" as reflected by the mean difference values of $-1.60,-1.55$ and -1.50 respectively.

Further, the results of the study reveal that perceived service quality is positively related to customer behavioural intentions. Behavioural Intentions were measured into four dimensions: Word-of-Mouth Communications, Purchase Intention, Price Sensitivity, and Complaining Behaviour. It is concluded that "Complaining Behaviour" and "Word-of-Mouth Communications" have a significant relationship with perceived service quality followed by purchase intentions and price sensitivity dimensions. Complaining behaviour involves any action by the customer that is triggered by perceived dissatisfaction such as poor network quality, high call charges, not keeping promises and unreliable services. Word-of-Mouth Communications includes a recommendation or communication to the other customer about services post perceiving or experiencing the services. The study has shown that unsatisfactory services strongly impact customer behaviour intents. With the expansion and intensification of the competition and the demand for new acquisitions, the concern about service quality has become more important. This study assumes greater significance as the issues related to telecommunication services in India have been investigated here with different objectives, and a wider scope. It is suggested that a perception of high quality of service leads to the success of the company which is evident in the intentions of the customers' behaviour such as high loyalty and a positive word-ofmouth.

The implications identified in this study enable the marketers, service providers, practitioners and academicians to focus on the improvement of service quality in this highly competitive sector. The findings will help them to formulate the strategies to improve long-term relationships with customers and supports customer retention with the telecom sector.

\section{Theoretical implications}

This research contributes to the existing service quality, customer's perception and behaviour intentions literature in several ways. The findings of the research have theoretical implications for service providers who are striving to organize their service offerings to meet customer expectations and goals. Service providers should develop strategies that promote positive behavioural responses to customer satisfaction and prohibit negative responses. Service providers should develop the process and policies in such a way that it is beneficial in meeting the desired service levels of the customers, preventing the occurrence of service problems, effectively treating dissatisfied customers, effectively solving service problems as they occur, and confronting customer complaints.

\section{Managerial implications}

The current study indicates that it is crucial for the Indian telecom service providers to know in advance what their customers' expectations are. The results of the present study are also useful for the telecom service providers of other developing countries such as Brazil, Russia, China, South-Africa, and Indonesia as they provide the comprehensive customer feedback on the telecom services acquired. Detailed evaluations need to be carried out to understand whether the sequence of activities in the service process is appropriate or not. The telecom operators may spend less time in solving customer's inquiries. Process standards must be reviewed frequently to ensure service compliance. Service quality should be measured periodically at regular intervals. The skillset, knowledge level and customer handling aspects of the service staff should align with service quality standards. The service provider should ensure that the service staff are very knowledgeable about the customers' day-to-day problems and issues so that they can provide prompt remedies/solutions.

\section{Recommendations, limitations \& future scope}

To improve the quality of service and customer behaviour, which is largely dependent on the quality of aftersale services offered, self-service solutions such as mobile self-care apps can make a significant contribution 
to improving customer service quality. Quicker response time and availability of maximum information over the mobile app such as usage, complaint update and tracking, new plans or schemes, feedback, payment options, etc. can be of great convenience for customers. In order to address customers' concerns and to improve their behavioural intentions, there is an urgent need for independent agencies to handle the customer escalations under the governance of the Telecom Regulatory Authority of India (TRAI). Another way is to set up a three-tier grievance handling mechanism, with the TRAI acting as a third level authority. As of now, a service provider is managing and has a two-tier grievance handling mechanism, which includes the call centre as the first level and the appellate authority as the last level.

Like all other research works, the current study also contains some limitations that provide opportunities for further research. The present study is cross-sectional. Due to ever-changing competitive scenarios and the dynamic nature of this industry, a longitudinal study would have revealed changes in perceptions of customers over time. Moreover, the study only examined the perception of customers regarding service and performance of service providers, whereas feedback and opinion from service providers may be further taken up regarding their difficulties in extending services and designing various service products to cope with the competition and meet customers' expectations. Since the survey was conducted only in Delhi/NCR, it cannot be understood as a representative of each province. The perception, demands, and behaviours of rural customers need to be further studied, as rural markets are going to be the markets of the future.

The present study has been conducted in Delhi/NCR, India. It can be extended further to all the major cities and towns of India, covering all the telecom service providers for more reliability and applicability of its findings. Moreover, a comparative study can also be conducted to measure the service quality gaps and customer behavioural intentions in the telecommunication sector of India and other developed countries to generalize the findings of the study in other countries as well. Since telecom services have become daily needs and the telecom service industry is highly dynamic, the views of customers may differ depending on purposes. To carry out a more elaborate study in this area, more consumer behaviour related to the core purposes of telecom usage such as voice calls, messages, internet, personal use, business purpose, etc. as well as service provider aspects such as cost-effectiveness and government policies supporting the service providers can be included.

\section{Funding}

Please supply all details required by any funding and grant-awarding bodies as Funding in a separate paragraph as follows: This research is not funded by any agency.

\section{Author contributions}

"Data collection and analysis has been done by Pankaj sharma. Deepika Jhamb wrote the first draft of the article. Amit Mittal was responsible for editing the language and proof-reading."

\section{Disclosure statement}

No conflict of interest with any party/agency.

\section{References}

Aggarwal, A., Goyal, J., \& Nobi, K. (2018). Examining the impact of leader-member exchange on perceptions of organizational justice: the mediating role of perceptions of organizational politics. Theoretical Economics Letters, 8(11), 2308-2329. https://doi.org/10.4236/tel.2018.811150

Alexandris, K., Zahariadis, P., Tsorbatzoudis, C., \& Grouios, G. (2004). An empirical investigation of the relationships among service quality, customer satisfaction and psychological commitment in a health club context. European Sport Management Quarterly, 4(1), 36-52.

https://doi.org/10.1080/16184740408737466

Al-Hashedi, A. H., \& Abkar, S. A. (2017). The impact of service quality dimensions on customer satisfaction in telecom mobile companies in Yemen. American Journal of Economics, 7(4), 186-193.

Anderson, R. E. (1973). Consumer dissatisfaction: The effect of disconfirmed expectancy on perceived product performance. Journal of Marketing Research, 10(1), 38-44. https://doi.org/10.1177/002224377301000106

Babakus, E., \& Mangold, W. G. (1992). Adapting the SERVQUAL scale to hospital services: an empirical investigation. Health Services Research, 26(6), 767. PMCID: PMC106985.

Baruah, P., \& Baruah, R. (2014). Telecom sector in India: Past, present and future. International Journal of Humanities and Social Science Studies, 1(3), 147-156.

Berry, L. L., Parasuraman, A., \& Zeithaml, V. A. (1994). Improving service quality in America: lessons learned. Academy of Management Perspectives, 8(2), 32-45. https://doi.org/10.5465/ame.1994.9503101072

Bolton, R. N., \& Drew, J. H. (1991). A multistage model of customers' assessments of service quality and value. Journal of Consumer Research, 17(4), 375-384. https://doi.org/10.1086/208564

Brown, J. D. (2002). The Cronbach alpha reliability estimate. JALT Testing \& Evaluation SIG Newsletter, 6(1).

Chopra, S., \& Chawla, P. (2018). Innovation, growth and intellectual property: a study of the Indian Telecom sector and the way forward. Journal of National Law University Delhi, 5(1), 40-60. https://doi.org/10.1177/2277401718787953

Choudhury, K. (2014). Service quality and customers' complaining behavior: a study of the Indian banking sector. Services Marketing Quarterly, 35(2), 123-137. https://doi.org/10.1080/15332969.2014.885361

Chowdhary, N., \& Prakash, M. (2007). Prioritizing service quality dimensions. Managing Service Quality: An International Journal, 17(5), 493-509. https://doi.org/10.1108/09604520710817325

Cronbach, L. J. (1951). Coefficient alpha and the internal structure of tests. Psychometrika, 16(3), 297-334. https://doi.org/10.1007/BF02310555 
Cronin Jr, J. J., \& Taylor, S. A. (1992). Measuring service quality: a reexamination and extension. Journal of marketing, 56(3), 55-68. https://doi.org/10.1177/002224299205600304

Cruz, V., \& Mendes, L. (2019). The influence of service quality on users' behavioural intentions in developing countries: a crosssectional study in Cape Verde's public hospitals. International Journal for Quality Research, 13(2), 361-380. https://doi.org/10.24874/IJQR13.02-08

David Mc, A. B. (2013). Service quality and customer satisfaction in the airline industry: A comparison between legacy airlines and low-cost airlines. American Journal of Tourism Research, 2(1), 67-77.

https://doi.org/10.11634/216837861302317

Dua, S. (2017). Digital India: opportunities and challenges. International Journal of Science Technology and Management, 6(3), 61-67.

Dubey, A., \& Srivastava, A. K. (2016). Impact of service quality on customer loyalty - A study on telecom sector in India. 10SR Journal of Business and Management (10SRJBM), 18(2), 45-55.

Howat, G., Crilley, G., \& McGrath, R. (2008). A focused service quality, benefits, overall satisfaction and loyalty model for public aquatic centres. Managing Leisure, 13(3-4), 139-161. https://doi.org/10.1080/13606710802200829

IBEF. (2019). Telecom industry in India. https://www.ibef.org/industry/telecommunications.aspx

Johnson, W. C., \& Sirikit, A. (2002). Service quality in the Thai telecommunication industry: a tool for achieving a sustainable competitive advantage. Management Decision, 40(7), 693-701. https://doi.org/10.1108/00251740210438526

Kang, G. Du., James, J., \& Alexandris, K. (2002). Measurement of internal service quality: application if the SERVQUAL battery to internal service quality. Managing Service Quality, 12, 278-291. https://doi.org/10.1108/09604520210442065

Kirk, J., Miller, M. L., \& Miller, M. L. (1986). Reliability and validity in qualitative research (Vol. 1). Sage. https://doi.org/10.4135/9781412985659

Kondasani, R. K. R., \& Panda, R. K. (2016). Service quality perception and behavioural intention: a study of Indian private hospitals. Journal of Health Management, 18(1), 188-203. https://doi.org/10.1177/0972063416639168

Kumar, A., Shankar, R., \& Debnath, R. M. (2015). Analyzing customer preference and measuring relative efficiency in telecom sector: A hybrid fuzzy AHP/DEA study. Telematics and Informatics, 32(3), 447-462. https://doi.org/10.1016/j.tele.2014.10.003

Kushwah, S. V., \& Bhargav, A. (2014). Service quality expectations and perceptions of Telecom sector in India. International Journal of Advancements in Technology, 5(1), 1-10.

Ladhari, R. (2009). A review of twenty years of SERVQUAL research. International Journal of Quality and Service Sciences, 1(2), 172-198. https://doi.org/10.1108/17566690910971445

Lee, Y. C., Wang, Y. C., Chien, C. H., Wu, C. H., Lu, S. C., Tsai, S. B., \& Dong, W. (2016). Applying revised gap analysis model in measuring hotel service quality. SpringerPlus, 5(1), 1191. https://doi.org/10.1186/s40064-016-2823-z

Lewis, B. R., \& Mitchell, V. W. (1990). Defining and measuring the quality of customer service. Marketing Intelligence \& Planning, 8(6), 11-17. https://doi.org/10.1108/EUM0000000001086

Liang, R. D., Chang, C. S., \& Wang, T. S. (2011). The effect of service responsiveness and social emotions on service outcomes: An empirical investigation of service firms. African Journal of Business Management, 5(8), 3155-3167.
Loke, S. P., Taiwo, A. A., Salim, H. M., Downe, A. G., \& Petronas, U. T. (2011). Service quality and customer satisfaction in a telecommunication service provider. In International Conference on Financial Management and Economics, 11, 24-29.

Mani, S. (2005). The dragon vs the elephant: Comparative analysis of innovation capability in the telecom industry of China and India. Economic and Political Weekly, 40(1), 4271-4283. https://www.jstor.org/stable/4417201

Manohar, S., Mittal, A., \& Marwah, S. (2019). Service innovation, corporate reputation and word-of-mouth in the banking sector - A test on multigroup-moderated mediation effect. Benchmarking: An International Journal, ahead-of-print. https://doi.org/10.1108/BIJ-05-2019-0217

Mathew, B., Narayanan, R., \& Mittal, A. (2019) A review of the perception of healthcare quality among patients and employees. Indian Journal of Public Health Research and Development, 10(9), 452-456.

https://doi.org/10.5958/0976-5506.2019.02469.0

Min, S., \& Khoon, C. C. (2014). Demographic factors in the evaluation of service quality in higher education: A Structural Equation Model (SEM) approach. International Journal of Marketing Studies, 6(1), 90.

https://doi.org/10.5539/ijms.v6n1p90

Ministry of Electronics \& Information technology. (2018). Digital India programme, government of India. http://digitalindia. gov.in/content/universal-access-mobile-connectivity

Munusamy, J., Chelliah, S., \& Mun, H. W. (2010). Service quality delivery and its impact on customer satisfaction in the banking sector in Malaysia. International Journal of Innovation, Management and Technology, 1(4), 398.

Naseer, A., Hu, B., \& Fukuda, K. (2012, June). HOME Q-Score: Assessing the quality of healthcare provisioning. In 2012 25th IEEE International Symposium on Computer-Based Medical Systems (CBMS, 1-6). IEEE.

https://doi.org/10.1109/CBMS.2012.6266395

Ojiaku, O. C., \& Osarenkhoe, A. (2018). Determinants of customers' brand choice and continuance intentions with mobile data service provider: The role of past experience. Global Business Review, 19(6), 1478-1493. https://doi.org/10.1177/0972150918780764

Ojo, O. (2010). The relationship between service quality and customer satisfaction in the telecommunication industry: Evidence from Nigeria. BRAND. Broad Research in Accounting, Negotiation, and Distribution, 1(1), 88-100.

Olshavsky, R. W., \& Miller, J. A. (1972). Consumer expectations, product performance, and perceived product quality. Journal of Marketing Research, 9(1), 19-21. https://doi.org/10.1177/002224377200900105

Pandey, N., \& Kumar, A. (2018). Responding to $4 \mathrm{G}$ telecom pricing war: ignore, accommodate or retaliate. Emerald Emerging Markets Case Studies, 8(2), 1-23.

https://doi.org/10.1108/EEMCS-11-2017-0251

Parasuraman, A., Berry, L. L., \& Zeithaml, V. A. (1991). Refinement and reassessment of the SERVQUAL scale. Journal of Retailing, 67(4), 420.

Parasuraman, A., Berry, L. L., \& Zeithaml, V. A. (1990). Guidelines for conducting service quality research. Marketing Research, 2(4).

Parasuraman, A., Berry, L. L., \& Zeithaml, V. A. (1993). More on improving service quality measurement. Journal of Retailing, 69(1), 140-148.

https://doi.org/10.1016/S0022-4359(05)80007-7

Parasuraman, A., Zeithaml, V. A., and Berry, L. L. (1988). Servqual: A multiple-item scale for measuring consumer perc. Journal of Retailing, 64(1), 12. 
Parasuraman, A., Zeithaml, V. A., \& Berry, L. L. (1985). A conceptual model of service quality and its implications for future research. Journal of Marketing, 49(4), 41-50. https://doi.org/10.1177/002224298504900403

Patel, B. K. (2018). A study on marketing strategy adopted by leading players of telecom sector in Gujarat state. Clear International Journal of Research in Commerce \& Management, 9(6). http://search.ebscohost.com/login.aspx?direct=tr ue\&db=bsh\&AN $=130686529 \&$ site $=$ eds-live

Paulrajan, R., \& Rajkumar, H. (2011). Service quality and customers preference of cellular mobile service providers. Journal of Technology Management \& Innovation, 6(1), 38-45. https://doi.org/10.4067/S0718-27242011000100004

Pedro, E., Mendes, L., \& Lourenço, L. (2018). Perceived service quality and student's satisfaction in higher education: the influence of teaching methods. International Journal for Quality Research, 12(1), 165-192.

Pitt, L. F., Watson, R. T., \& Kavan, C. B. (1995). Service quality: a measure of information systems effectiveness. MIS Quarterly, 19(2), 173-187. https://doi.org/10.2307/249687

Prasad, R. (2018). Ascendant India, digital India: how net neutrality advocates defeated Facebook's Free Basics. Media, Culture \& Society, 40(3), 415-431. https://doi.org/10.1177/0163443717736117

Qadri, U. A. (2015). Measuring service quality expectation and perception using SERVQUAL: A gap analysis. Business and Economics Journal, 6(3), 1-6. https://doi.org/10.4172/2151-6219.1000162

Ravichandran, K., Bhargavi, K., \& Kumar, S. A. (2010). Influence of service quality on banking customers' behavioural intentions. International Journal of Economics and Finance, 2(4), 18-28. https://doi.org/10.5539/ijef.v2n4p18

Reichheld, F. F., \& Sasser, W. E. (1990). Zero defections: quality comes to services. Harvard Business Review, 68(5), 105-111.

Ryu, K., Lee, H. R., \& Gon Kim, W. (2012). The influence of the quality of the physical environment, food, and service on restaurant image, customer perceived value, customer satisfaction, and behavioral intentions. International Journal of Contemporary Hospitality Management, 24(2), 200-223. https://doi.org/10.1108/09596111211206141

Selvakumar, J. J. (2016). Impact of service quality on customer satisfaction in public sector and private sector banks. Purushartha: A Journal of Management Ethics and Spirituality, 8(1).

Sharma, P. (2017). Service quality and customer behaviour intentions in Indian telecom sector. In Proceedings of IEEEFORUM International Conference (pp. 7-10).

Sharma, P., \& Jhamb, D. (2017). Measuring service quality in the telecom industry in India. International Journal of Management Studies, 4, 123-131.

http://www.researchersworld.com/ijms/

Shine. (2013). Telecom industry set for growth in 2013.

http://info.shine.com/ Industry-Information/Telecom/183.aspx
Siwach, J., \& Kumar, A. (2015). Vision of digital India: dreams comes true. IOSR Journal of Economics and Finance, 6(4), 66-71.

Telecom Regulatory Authority of India (TRAI). (2017). Telecom Subscription Reports. http://www.trai.gov.in/release-publication/reports/telecom-subscriptions-reports

Uppal, V., \& Mittal, A. (2019). Antecedents of post purchase consumer dissatisfaction in household white goods. Journal of Advanced Research in Dynamical \& Control Systems, 11(5), 1958-1966.

Wong, I. A., \& Dioko, L. D. A. (2013). Understanding the mediated moderating role of customer expectations in the customer satisfaction model: The case of casinos. Tourism Management, 36, 188-199.

https://doi.org/10.1016/j.tourman.2012.10.010

Yadav, H. R. (2014). A comparative study on performance of public sector and private sector telecommunications with reference to wireless services in India. International Journal of Research, 1, 535-544.

Yadav, N. (2014). Total interpretive structural modelling (TISM) of strategic performance management for Indian telecom service providers. International Journal of Productivity and Performance Management, 63(4), 421-445. https://doi.org/10.1108/IJPPM-04-2013-0081

Yore, M. M., Ham, S. A., Ainsworth, B. E., Kruger, J., Reis, J. P., Kohl III, H. W., \& Macera, C. A. (2007). Reliability and validity of the instrument used in BRFSS to assess physical activity. Medicine \& Science in Sports \& Exercise, 39(8), 1267-1274. https://doi.org/10.1249/mss.0b013e3180618bbe

Zehendner, E., \& Feillet, D. (2014). Benefits of a truck appointment system on the service quality of inland transport modes at a multimodal container terminal. European Journal of $\mathrm{Op}$ erational Research, 235(2), 461-469. https://doi.org/10.1016/j.ejor.2013.07.005

Zeithaml, V., Berry, L., \& Parasuraman, A. (1996). The behavioural consequences of service quality. Journal of Marketing, 60(2), 2-22. https://doi.org/10.1177/002224299606000203

Zeithaml, V. A., Bitner, M. J., \& Gremler, D. D. (1996). Services marketing. McGraw Hill.

Zeithaml, V. A., Bitner, M. J., Gremler, D. D., \& Pandit, A. (2006). Services marketing: Integrating customer focus across the firm (4th ed.). McGraw-Hill/Irwin.

Zeithaml, V. A., Parasuraman, A., \& Berry, L. L. (1990). Delivering quality service: perceptions and expectations. Free Press.

Zeithaml, V. A., Parasuraman, A., \& Malhotra, A. (2000). Eservice quality: definition, dimensions and conceptual model. Marketing Science Institute, Cambridge, MA, working paper.

Zikmund, W. G., Babin, B. J., Carr, J. C., \& Griffin, M. (2013). Business research methods (9th International Edition). SouthWestern Cengage Learning, Canada. 


\section{APPENDIX. MEASUREMENT ITEMS}

1. Service Quality (Expectations) - Please indicate the agreement to which you think firms offering telecom services should possess the features described by each statement on seven-point scale $(1=$ Strongly Disagree, $2=$ Disagree, $3=$ Slightly Disagree, 4 = Neutral, 5 = Slightly Agree, $6=$ Agree and 7 = Strongly Agree) (Perasuraman et al., 1988)

\begin{tabular}{|c|c|c|}
\hline Items & Statements & Dimensions \\
\hline E1 & $\begin{array}{l}\text { A telecom service provider should have up-to-date equipment like Infrastructure and Technology } \\
\text { to offer superior customer service }\end{array}$ & \multirow{4}{*}{$\begin{array}{l}\text { Tangibility } \\
\text { (E1 to E4) }\end{array}$} \\
\hline E2 & $\begin{array}{l}\text { A service provider should have visually appealing signage, advertisements, pamphlets and other } \\
\text { displays }\end{array}$ & \\
\hline E3 & The customer service staff should be well groomed & \\
\hline E4 & $\begin{array}{l}\text { The appearance of the physical facilities of this telecom service provider should be in line with } \\
\text { telecom services provided }\end{array}$ & \\
\hline E5 & $\begin{array}{l}\text { When the telecom service provider promises to do something by a certain time, they should stick to } \\
\text { timeline }\end{array}$ & \multirow{5}{*}{$\begin{array}{l}\text { Reliability } \\
\text { (E5 to E9) }\end{array}$} \\
\hline E6 & When the customer has problems, the telecom service provider should be sympathetic and assuring & \\
\hline E7 & The telecom service provider should be reliable & \\
\hline E8 & The service provider should provide its services as per the committed timeline & \\
\hline E9 & The service provider should keep their accurate records & \\
\hline E10 & $\begin{array}{l}\text { The service provider shouldn't be expected to tell customers exactly when services will be } \\
\text { performed }(-)\end{array}$ & \multirow{4}{*}{$\begin{array}{l}\text { Responsiveness } \\
\text { (E10 to E13) }\end{array}$} \\
\hline E11 & It is not realistic for customers to expect prompt service from customer service staff $(-)$ & \\
\hline E12 & The service provider customer service staffs don't always have to be willing to help customers $(-)$ & \\
\hline E13 & $\begin{array}{l}\text { It is okay if customer service staffs are too busy to respond to customer request promptly } \\
(-)\end{array}$ & \\
\hline E14 & Customers should be able to trust employees (customer service staff) of these service providers & \multirow{4}{*}{$\begin{array}{l}\text { Assurance } \\
(\mathrm{E} 14 \text { to } \mathrm{E} 17)\end{array}$} \\
\hline E15 & Customer should feel secure in dealing with service provider's customer service staff & \\
\hline E16 & The service provider customer service staffs should be polite & \\
\hline E17 & The customer service staffs should get adequate support from organization to do their job well & \\
\hline E18 & Your telecom service provider should not be expected to give customers individual attention $(-)$ & \multirow{5}{*}{$\begin{array}{l}\text { Empathy } \\
\text { (E18 to E22) }\end{array}$} \\
\hline E19 & The customer service staffs cannot be expected to give customers personal attention $(-)$ & \\
\hline E20 & It is unrealistic to expect customer service staffs to know what the needs of their customers are ( -$)$ & \\
\hline $\mathrm{E} 21$ & $\begin{array}{l}\text { It is unrealistic to expect these telecom service providers to have its customer's best interests at heart } \\
(-)\end{array}$ & \\
\hline $\mathrm{E} 22$ & $\begin{array}{l}\text { The service provider shouldn't be expected to have operating hours convenient to all their } \\
\text { customers }(-)\end{array}$ & \\
\hline
\end{tabular}

(-) denotes reverse -coded items.

2. Service Quality (Perceptions) - Please indicate the agreement to which you believe your telecom service provider has the feature described by each statement on seven-point scale $(1=$ Strongly Disagree, $2=$ Disagree, 3 = Slightly Disagree, $4=$ Neutral, $5=$ Slightly Agree, $6=$ Agree and $7=$ Strongly Agree) (Parasuraman et al., 1988)

\begin{tabular}{|c|l|c|}
\hline Items & \multicolumn{1}{|c|}{ Statements } & Dimensions \\
\hline P1 & $\begin{array}{l}\text { A telecom service provider has up-to-date equipment like Infrastructure and Technology to offer } \\
\text { superior customer service }\end{array}$ & Tangibility \\
P2 & A service provider has visually appealing signage, advertisements, pamphlets and other displays & (P1 P4) \\
\hline P3 & The customer service staff are well groomed & $\begin{array}{l}\text { The appearance of the physical facilities of this telecom service provider is in keeping with the type } \\
\text { of telecom services provided }\end{array}$ \\
\hline P4
\end{tabular}




\begin{tabular}{|c|c|c|}
\hline Items & Statements & Dimensions \\
\hline P5 & When the telecom service provider promises to do something by a certain time, they do so & \multirow{5}{*}{$\begin{array}{l}\text { Reliability } \\
\text { (P5 to P9) }\end{array}$} \\
\hline P6 & A telecom service providers are sympathetic and assuring while resolving my problem & \\
\hline P7 & The telecom service provider is reliable & \\
\hline P8 & The service provider provides its services as per their committed timeline & \\
\hline P9 & The service provider keeps its records accurately & \\
\hline P10 & The service provider does not tell exactly when services will be performed ( - ) & \multirow{4}{*}{$\begin{array}{l}\text { Responsiveness } \\
\text { (P10 to P13) }\end{array}$} \\
\hline P11 & I do not receive prompt service from service provider customer service staff $(-)$ & \\
\hline P12 & The customer service staff of service provider is not always willing to help customers ( - ) & \\
\hline P13 & The customer service staffs are too busy to respond your request promptly $(-)$ & \\
\hline P14 & I can trust the employees (customer service staff) of these service providers & \multirow{4}{*}{$\begin{array}{l}\text { Assurance } \\
\text { (P14 to P17) }\end{array}$} \\
\hline P15 & I feel secure in dealing with service provider's customer service staff & \\
\hline P16 & The service provider customer service staffs are polite & \\
\hline P17 & The customer service staffs gets adequate support from organization to do their job well & \\
\hline P18 & Your telecom service provider does not give you individual attention ( - ) & \multirow{5}{*}{$\begin{array}{l}\text { Empathy } \\
\text { (P18 to P22) }\end{array}$} \\
\hline P19 & The customer service staffs of service provider do not give you personal attention. ( - ) & \\
\hline P20 & The customer service staffs of service provider do not know what the customer's needs are $(-)$ & \\
\hline P21 & The telecom service providers does not have customer's best interests at heart $(-)$ & \\
\hline P22 & The telecom service provider does not have operating hours convenient to all their customers $(-)$ & \\
\hline
\end{tabular}

(-) denotes reverse -coded items.

3. Customer Behavioural Intentions - Please indicate the agreement to which you feel about your telecommunication service provider described by each statement on seven-point scale $(1=$ Strongly Disagree, $2=$ Disagree, $3=$ Slightly Disagree, 4 = Neutral, 5 = Slightly Agree, $6=$ Agree and $7=$ Strongly Agree) (Zeithaml et al., 1996)

\begin{tabular}{|c|c|c|}
\hline Items & Statements & Dimensions \\
\hline BI 1 & Say positive things about a service provider to other people & \multirow{3}{*}{$\begin{array}{l}\text { Word-of-Mouth } \\
\text { Communication } \\
\text { (BI } 1 \text { to BI 3) }\end{array}$} \\
\hline BI 2 & Recommend a service provider to someone who seeks advice & \\
\hline BI 3 & Encourage friends and relatives to migrate with a service provider & \\
\hline BI 4 & Consider a service provider of your first choice to fulfil telecommunication needs & \multirow{3}{*}{$\begin{array}{l}\text { Purchase Intentions } \\
\text { (BI } 4 \text { to } \mathrm{BI} 6 \text { ) }\end{array}$} \\
\hline BI 5 & Do more usage with a service provider in the next few months & \\
\hline BI 6 & Do less usage with a service provider in the next few months & \\
\hline BI 7 & Take some of my usage to competitors that offers better price & \multirow{3}{*}{$\begin{array}{l}\text { Price Sensitivity } \\
\text { (BI } 7 \text { to BI 9) }\end{array}$} \\
\hline BI 8 & Continue to use same service provider if it's prices increase somewhat & \\
\hline BI 9 & Pay a higher price than competitors charge for the better benefits & \\
\hline BI 10 & Switch to a competitor if I experience a problem with telecom services & \multirow{4}{*}{$\begin{array}{l}\text { Complaining } \\
\text { Behaviour } \\
\text { (BI } 10 \text { to BI 13) }\end{array}$} \\
\hline BI 11 & Complain to other customers if experienced a problem & \\
\hline BI 12 & Complain to external agencies such as the Consumer Protection Council & \\
\hline BI 13 & Complain to a service provider's employees if I experienced a problem & \\
\hline
\end{tabular}

